\title{
Social Responsibility And Relation To The Quality Of Services Provided To The Elderly
}

\section{Mabroka Mahmoud Mohamed Olik (PhD)}

Assistant Professor of Community Organization

Faculty of Social Work- Helwan University

Emy Mohamed Saad El Deen Mohamed Oqr (PhD)

Assistant Professor of Community Organization

Higher Institute of Social work, Kafr Saqr - Al-Sharqueya 



\section{Social Responsibility And Relation To The Quality Of Services Provided To The Elderly}

\section{ABSTRACT:}

The study aims to identify the relationship between social responsibility and the quality of services provided to the elderly, "by determining the relationship between understanding and perception, interest, participation as indicators of social responsibility and indicators of the quality of services provided to the elderly (efficient provision of services for the elderly, easy access to service, continuous improvement of services for the elderly, the security and safety of the environment in which the service is provided), and this study belongs to the descriptive studies. The study has used the comprehensive social survey methodology (for both the elderly and the officials) at the elderly care associations. A questionnaire form has been applied to the elderly whose number is (88) elderly, also a questionnaire form to the officials whose number is (36) individual. The study has proved the validity of its hypotheses, as it proved that there is a direct statistical relationship between the social responsibility of officials and the quality of services provided to the elderly, this makes us accept the hypotheses of the study.

\section{KEY WORDS:}

Social Responsibility - Quality Of Services - The Elderly

\section{INTRODUCTION:}

In any society, the elderly of both sexes are those who have offered the society the best of giving and they had a head start on their society's growth and progress through the constructive and connected process of contribution through successive times, which has brought the society to its current cultural, social, economic, political and civilizational status (Fathalbab, 2003, p. 297).

The world is witnessing a steady increase in the number of the elderly; According to the WHO report, the elderly had reached (688) million in (2006), and the number is expected to increase to about (1.2) billion by (2025), and the number is expected to reach about (2) billion by the year (2050). In addition the proportion of the elderly aged 80 or over will reach $(20 \%)$ of the total elderly in 2050 (WHO, 2018).

Statistical data in Egypt also indicates that the number of the elderly aged 60 years or over has increased steadily, as the number of elderly reached 6.542 million in 2018; this is $6.7 \%$. This ratio is 
expected to rise to $11.5 \%$ in 2031 (Central Agency for Public mobilization and Statistics, 2018).

Such an increase in the number of the elderly is, of course, accompanied by an increase in their needs and problems. Aging is not just pure biological processes that reflect their effects on the physical and physiological changes the elderly undergo, but is also a social phenomenon (United Nations Population, 2002, p.60).

Therefore, governmental and non-governmental institutions seek to provide integrated care for the elderly according to strategies and framework through a plan based on scientific research and development that is appropriate for the elderly needs of integrated care (Lopez et al, 2006, p.123).

Social care policies concerning care for the elderly in developed and developing societies have defined the aims of this care in (appropriate income, improvement of mental health, appropriate home, continuous improvement of services, provision of appropriate health care, provision of effective community services, respect for the freedom of everyone to plan and manage their lives) .This will help solve the problems of the elderly and satisfy their different needs (Suge, 2005, P5).

The study, Ziong (2008) confirmed the effectiveness of implementing programs and projects for the elderly in satisfying their needs and confronting their problems through formal and informal social care and the need to achieve exchange and partnership between social organizations in their community-based care process.

In the light of this, these organizations seek to implement the quality system in their services to the elderly, where quality means excellence and that the service meets good specifications and to work properly from the very first sight, while relying on business evaluation to see how well performance is improved, and to design products and provide future services to customers according to their needs, and achieve continuous improvement to these services (Eduard, 2007, p 195).

Therefore, the success and continuity of any service institution especially, the elderly care institutions depends on the extent to which it has achieved the goals for which it was established, and therefore these institutions need a scientific tool on which they can judge the effectiveness of their activities and the processes necessary to achieve their desired objectives and can determine whether the target results 
are different from the achieved results which can only be done by measuring the quality of services provided to the elderly.

The study, Adam \& Saulter (2000) has confirmed that the measurement of quality of services in general is difficult because of many factors and reasons, the most important of which is that the service is intangible and is affected by the surrounding environment, as well as the difference in service characteristics from one service to another. This has led many service quality researchers to try to establish common standards that can be applied to certain service institutions with similar activity, to serve as essential elements for achieving minimum quality in these services.

There are indications of the quality of services provided to the elderly in these institutions, which are:

The efficient provision of services to the elderly, where these institutions provide an integrated teamwork, specific tools, and services provided in a special way, and community participation supporting elderly care institutions in a manner that ensures quality of service to the elderly, as proved by the results of the study (Crawley, 2007). The quality of the services provided to the elderly is also related to the presence of a distinguished board of directors, efficient staff, the appropriate potential of the institution, distinguished services, and the activation of community participation to support the institution, and the satisfaction of the elderly with the residence in the institution, as proved by the study (Mohammad, 2009).

The results of the study, Wotter \& Goakim, (2008) also confirmed that upgrading the quality of services provided by the elderly care institutions can only be achieved by providing the funding required implementing programs and providing them with the services they need, to reach an acceptable level of satisfaction while staying in the institution. It is also related to the provision of the activities which appeal to the elderly, the provision of resources and means for the promotion of these services, the need to communicate between (the elderly person classification, the elderly person's sitter classification, social worker classification) to foster a spirit of cooperation among them regarding the problems and needs of the elderly, as proved by the study (Shaiira, 2013).

The ease with which the elderly have access to service, as the quality of services provided to the elderly is linked to the ease of access to services by setting up easy procedures for obtaining service at the time the elderly person wants, and providing them where they 
want it, In addition to receiving the service when requested, the time the elderly wait for the service and easy access to the service premises. This has been proven by (Al Dhamour, 2005, p. 443).

The continuous improvement of services for the elderly. The social worker in the elderly care institutions follows several indicators of quality of services for the elderly, which are: the elderly person realizes he/she is with members of their family, indicators of participation of workers in service planning, social responsibility for the elderly, team work indicators and information system; The continuous evaluation and development of services in a way that ensures their effectiveness and that has been proven by the study of both (Al-Rashidi, 2008), (Donovan, 2013). Measuring the satisfaction of the elderly is one of the most important mechanisms for evaluating quality of services, which is an essential step in analyzing strengths and weaknesses in performance, and in planning scenarios for development and continuous renewal of work. It is also an important indicator for measuring service development, reflecting the success of the service provider in meeting the needs and expectations of the elderly from the service provided, as proven by the study (Kotler, 2010). The satisfaction of the elderly cannot be achieved without getting the greatest benefit from the services provided by the institutions, as proven by the study (Szwarc, 2005).

The security and safety of the environment in which the service is provided, as the results of the study Elley, (2003) \& Eweda, (2000) confirmed that the quality of life of the elderly in the shelter institutions requires the provision of certain characteristics in the environment. They must have comfortable seating, dining facilities, the means, equipment and beds so that the foundation is simple to fit the conditions of the elderly, the staff, activities and selection opportunities for the elderly, and the participation of the community, friends and family in their care within the institution, which affects the satisfaction of the elderly with the services provided for them by the elderly care institutions .

The achievement of the above indicators is linked to the social responsibility of the workers in these institutions, where social responsibility is considered a mean and a tool for achieving the end, namely, comprehensive development, especially human resources development, and upgrading the services provided to the beneficiaries (Carol, 1999, p. 286). 
Therefore, social responsibility, while self-forming, and part of the building of the personality, is largely a social product, because it is learned and acquired and it grows gradually through social upbringing and through its institutions such as: The family, school, media, and places of worship that work to develop and improve it in accordance with the requirements of society, and that a person's ignorance of taking responsibility, absence or weakness of responsibility affects the society, as societies are built and developed by their members who have a duty to their societies. (Kyung, 2002, P89).

The study of social responsibility is considered a social necessity because of the spread of many manifestations of reluctance to participate, cooperate and take responsibilities, and lack of awareness of social duties, because when every member of the society takes responsibility toward others whose care and welfare are his/her responsibility, and toward the work they do ,this affects the progress of society and the improvement of the service provided to beneficiaries (William, et.al, 2006, p. 3).

The development of social responsibility is carried out through the family by the father and the mother, as the democratic parenting style in dealing with children makes them more socially responsible than they are when the parents use the authoritarian style, which contributes to the development of their children's social responsibility and this has been proved by the study (Michelle, 2003).

There are indicators of social responsibility that the employees of the elderly care institutions must adhere together in order to achieve the quality of the services provided to them, which are:

- Understanding: This includes the extent to which officials understand their roles toward the elderly group in the institution and the key actors of its members, their understanding of the motives of the behavior they adopt in the service of its objectives, as the correct understanding supports the participation of the individual in taking their responsibilities in a way that benefits the public interest. The awareness and understanding of officials in the elderly care institutions of the boundaries of social responsibility affect improving the quality of life of the elderly through training in basic life skills, including the skill of communicating with others and dealing with them inside or outside the institution. The skills of dialogue with others to address the problems and needs of the elderly by helping the elderly understand their past and present, their different roles, their habits and attitudes, and their societal values, as proved by the study of (Wallace, 2007) \& (Ismail, 2014). 
- Attention: To draw the attention of the elderly and show interest in them through the positive attitudes of the service provider, psychological and mental preparation to meet the elderly and goodlooking, attractive smile, effective positive behavior and selfconfidence.....,etc. all of them are motivations, which awaken the desire of the elderly to get the service they want, and it also promotes the permanent loyalty of the elderly to get the service and to continue to receive the service from the institution (Mahmoud, 2002, P. 217).

- Participation: it means the officials must understand the processes that lead to supporting social responsibility in the institution which has conditions of care, upbringing, and emphasizing the participation of others in decision-making, socially acceptable actions and ethical behavior of adults for all groups of the society. Participation is the cornerstone in building any society. It is a means of forming new social values and reaching a positive citizen in the life of his/her community, as confirmed by the results of the study (Kennemer, 2002).

In the light of the above, the study attempts to answer the following questions: (What are the indicators of social responsibility of social workers and workers and their relation to the quality of services provided to the elderly? What are the quality indicators of services provided to the elderly? ).

\section{Importance of the Study:}

1. The Egyptian society is interested in the elderly group in the society as a result of the increase in their number, which reached $6.7 \%$ in 2018 (Central Agency for Public mobilization and Statistics, 2018).

2. The social responsibility of social workers and officials in the elderly care institutions contributes to achieving the quality of the services provided to them through (understanding, cooperation, commitment, solidarity, attention, respect and serious participation).

3. To clarify the effective role that the elderly care institutions can play in the social care of the elderly by improving the quality of services for the elderly in order to solve their problems and satisfy their needs.

\section{Research Goals:}

The study seeks to achieve a main goal which is "determining the relationship between the social responsibility of officials in the elderly care institutions and the quality of services provided to them" and this 
goal can be achieved through the following sub-goals (defining the relationship between understanding and perception, interest, participation as indicators of social responsibility and indicators of the quality of services provided to the elderly).

\section{Study Hypotheses:}

The study seeks to test the validity of the following main hypothesis: "There is a statistically significant correlation between the social responsibility of officials and the quality of services provided to the elderly." This hypothesis can be tested through the following subassumptions (there is no statistically significant correlation between understanding and perception as an indicator of social responsibility and indicators of the quality of services provided to the elderly), While there is a statistically significant positive relationship between interest and participation as indicators of social responsibility and indicators of the quality of services provided to the elderly.

\section{Theoretical Guidelines of the Research:}

The study was based on the quality of service model, which assumes that in order to develop social organizations, the concept of Excellence service for clients or Customers should be applied, and this concept is intended to provide services to customers, taking into account quality of service indicators for beneficiaries, which are:(Speed in completion or efficient service delivery, providing service with respect and appreciation to the beneficiaries, establishing special regulations which organize the process of obtaining service, ease of procedures for obtaining service, lack of distinction or distinction between beneficiaries when providing service, continuous improvement of service to beneficiaries through the mastery of (userfriendly and entrepreneurial) the skills of dealing with the beneficiaries and through entrepreneurship ; putting into consideration the security and safety of the environment in which services are provided to beneficiaries.) (Abu Al-Naser, 2009, p. 295)

The reason for using this model is that it is a model of quality of services provided to the elderly and is appropriate for descriptive studies, and it is related to measuring the quality indicators of services provided to the elderly.

\section{Concepts:}

\section{Social responsibility:}

It means the status of a person who is asked about something that he/she is liable for. (Arabic Language Academy, 2010, P. 299). 
It is also an awareness and vigilance of the individual and the awareness of his / her conscience and his / her conduct of the personal duty toward himself / herself and the duty toward others (Abu AlNaser, 2016, p. 59).

It is also known as a social trend and a model of behavior that includes good citizenship in the individual's community (Starrett, 1996, p.536).

\section{Social responsibility procedurally means in this study:}

The degree and level of (interest, understanding, participation) of social workers and workers of the quality of services for the elderly.

\section{Quality of services:}

It is intended to identify the needs of customers and achieve their desires effectively without any defects, in addition to achieving continuity in improving performance (Barton \& Marson, 1999, p.61).

It is also the difference that separates the customer from the service, and the quality that they feel after using the service, or after receiving it (Gerard \&Michel, 1992, P.45).

\section{The quality of services procedurally means in this study:}

The degree and level of (efficient provision of services for the elderly, easy access to service, continuous improvement of services for the elderly, the security and safety of the environment in which the service is provided).

\section{METHODOLOGY:}

The study is considered a descriptive study. The study has used the comprehensive social survey methodology of the officials in the elderly care institutions whose number is (36) people, as well as the comprehensive social survey methodology of the elderly whose number is ( 88 ) elderly, The elderly care institutions have been chosen in Cairo Which :(Al-Entesar, Atbaa Alsadequeen Alawael, Basmat Amal, Rawaat Aleman, Hadeya Barakat). This is due to the diversity of programs they offers to the elderly and help them integrate into society, whether social, economic and educational or health programs. These institutions seek to implement the quality system in their services to the elderly. The societies agreed that two researchers do the study. 


\section{- Study tools: Data collection tools were:}

(1) A questionnaire form to measure social responsibility and its relation to the quality of services provided to the elderly:

The two researchers conducted a questionnaire form to measure social responsibility of the workers by referring to the theoretical heritage, and the previous studies related to the subject of the study. Face validity was done to the tool after presentation to (8) of the members of the staff of the Faculty of social work University of Helwan, depending on a minimum of agreement rate not less than (75\%), deleting some phrases and rephrasing some. According to this the form has been finally phrased. A reliability statistic has been done to a sample of (10) people of the elderly using Cronbach Alpha coefficient and reliability coefficient is (0.94), and it is an appropriate level of reliability statistic.

(2) A questionnaire form of the elderly about the social responsibility and its relation to the quality of services provided to them: The two researchers conducted a questionnaire form of the elderly by referring to the theoretical heritage, and the previous studies related to the subject of the study. Face validity was done to the tool after presentation to (8) of the members of the staff of the Faculty of social work University of Helwan, depending on a minimum of agreement rate not less than $(75 \%)$, deleting some phrases and rephrasing some. According to this the form has been finally phrased. A reliability statistic has been done to a sample of (10) people of the elderly using Cronbach Alpha coefficient and reliability coefficient is (0.92), and it is an appropriate level of reliability statistic.

Table (1) shows Cronbach Alpha coefficient for measuring the reliability of the Study tools:

\begin{tabular}{|l|l|l|l|l|l|}
\hline \multirow{2}{*}{$\begin{array}{l}\mathrm{N} \\
0\end{array}$} & \multirow{2}{*}{ indicators } & officials & Number of \\
\cline { 3 - 6 } & phrases & $\begin{array}{l}\text { Indicator } \\
\text { reliability }\end{array}$ & $\begin{array}{l}\text { Num } \\
\text { ber } \\
\text { of } \\
\text { phra } \\
\text { ses }\end{array}$ & $\begin{array}{l}\text { Indic } \\
\text { ator } \\
\text { reliab } \\
\text { ility }\end{array}$ \\
\hline 1 & Understanding, and perception & 7 & 0.840 & & \\
\hline 2 & attention & 7 & 0.936 & & \\
\hline 3 & Participation & 7 & 0.895 & 7 & 0.928 \\
\hline 4 & Efficiency of service delivery & 7 & 0.935 & 7 & 0.832 \\
\hline 5 & Easy access to service & 7 & 0.908 & 7 & 0.851 \\
\hline 6 & $\begin{array}{l}\text { Continuous improvement of the service provided to } \\
\text { the elderly }\end{array}$ & 7 & 0.896 & 7 & 0.901 \\
\hline 7 & $\begin{array}{l}\text { the security and safety of the environment in which } \\
\text { service is provided to the elderly }\end{array}$ & 7 & 0.916 & 7 & 0.920 \\
\hline General reliability & 49 & 0.940 & 28 & \\
\hline
\end{tabular}




\begin{tabular}{|c|c|}
\hline Egyptian Journal of Social Work (EJSW) & http://ejsw.journals.ekb.eg \\
\hline Print ISSN: 2356-9204 Online ISSN: $2356-9212$ & Vol 10, Issue 1, June 2020 \\
\hline
\end{tabular}

- Statistical analysis methods: Period of collecting data was from $25 / 10 / 2019$ to $25 / 12 / 2019$, the data have been processed through a computer using program (SPSS. V. 25.0) statistical packages for the social sciences, statistical methods were applied as follows: Frequencies and percentages, arithmetic average, standard deviation, Cronbach Alpha reliability coefficient, The Spearman correlation coefficient.

- The difficulties encountered by the researchers during data collection and how to overcome them:

- The difficulty of reaching elderly homes applying the quality of services system, and the researchers referred to the Ministry of Solidarity to know the role that is subject to the quality system.

- Some institutions maintained cooperation with the researchers until the researchers obtained the approval of the institutions to which the study was applied.

\section{Results:}

Table (2) shows Study community description

\begin{tabular}{|c|c|c|c|c|c|c|}
\hline \multirow{2}{*}{ No } & \multirow[b]{2}{*}{ Dimension } & \multirow{2}{*}{$\begin{array}{l}\text { Study community } \\
\text { description }\end{array}$} & \multicolumn{2}{|c|}{ the officials $\mathrm{N}=(36)$} & \multicolumn{2}{|c|}{ The elderly $\mathrm{N}=(88)$} \\
\hline & & & $\mathrm{f}$ & $\%$ & $\mathrm{f}$ & $\%$ \\
\hline \multirow{2}{*}{1} & \multirow{2}{*}{ Gender } & female & 15 & 41.66 & 34 & 38.63 \\
\hline & & Male & 21 & 58.33 & 54 & 61.36 \\
\hline \multirow{2}{*}{2} & \multirow{2}{*}{ age } & Average & \multicolumn{2}{|c|}{53.53} & & 67.42 \\
\hline & & Standard deviation & & & \multicolumn{2}{|c|}{10.35} \\
\hline
\end{tabular}

The previous table shows that: Study community description for the officials is as follows: First came; males (58.33\%), second came; females $(41.66 \%)$, their age average is ( 53.53) and standard deviation (11.083), as for the elderly, First came; males(61.36\%), second came; females $(38.63 \%)$ their age average is $(67.42)$ and standard deviation (10.35).

Table (3) shows understanding and perception of the staff of the elderly care institutions $\mathrm{N}=(36)$

\begin{tabular}{|c|l|c|c|c|}
\hline No & \multicolumn{1}{|c|}{ Phrase } & \multicolumn{1}{|c|}{$\mathbf{A}$} & $\boldsymbol{\sigma}$ & order \\
\hline 1 & $\begin{array}{l}\text { I am committed to the aims of the institution when } \\
\text { providing service to the elderly }\end{array}$ & 2.889 & 0.398 & 1 \\
\hline 2 & $\begin{array}{l}\text { I understand the regulations and legislations linked to } \\
\text { providing service to the elderly }\end{array}$ & 2.389 & 0.599 & 7 \\
\hline 3 & $\begin{array}{l}\text { I realize the problems that hinder the quality of the services } \\
\text { provided to the elderly }\end{array}$ & 2.472 & 0.696 & 6 \\
\hline 4 & $\begin{array}{l}\text { I realize the conditions and the standards of the quality of } \\
\text { the services provided to the elderly }\end{array}$ & 2.583 & 0.5 & 3 \\
\hline 5 & $\begin{array}{l}\text { I understand my job roles linked to the quality of the } \\
\text { services provided to the elderly }\end{array}$ & 2.528 & 0.56 & 5 \\
\hline 6 & I understand the nature of the needs of the elderly & 2.667 & 0.586 & 2 \\
\hline 7 & $\begin{array}{l}\text { I motivate the teamwork to provide the best service to the } \\
\text { elderly }\end{array}$ & 2.556 & 0.607 & 4 \\
\hline
\end{tabular}




\begin{tabular}{|c|c|}
\hline Egyptian Journal of Social Work (EJSW) & http://ejsw.journals.ekb.eg \\
\hline Print ISSN: 2356-9204 Online ISSN: 2356-9212 & Vol 10, Issue 1, June 2020 \\
\hline
\end{tabular}

\section{The previous table shows that:}

The level of understanding and perception of the staff of the elderly care institutions is high with arithmetic average (2.583), first came; I am committed to the aims of the institution when providing service to the elderly with arithmetic average (2.889), second came: I understand the nature of the needs of the elderly with arithmetic average (2.667), finally, I understand the regulations and legislations linked to providing service to the elderly with arithmetic average (2.389).

This may be due to the officials understanding of their roles within the organization and their understanding of the problems and needs of the elderly and the skills they need to help them live in society, and this was proven by the study of both (Wallace, 2007), (Ismail, 2014).

Table (4) shows the attention of the staff of the elderly care institutions $\mathrm{N}=(\mathbf{3 6})$

\begin{tabular}{|c|l|c|c|c|}
\hline No & \multicolumn{1}{|c|}{ Phrase } & \multicolumn{1}{|c|}{$\mathbf{A}$} & order \\
\hline 1 & $\begin{array}{l}\text { I am keen on attending the seminars the institution } \\
\text { organizes for developing the service to the elderly }\end{array}$ & 2.444 & 0.652 & 4 \\
\hline 2 & $\begin{array}{l}\text { I am keen on contacting the societal leaderships to } \\
\text { provide support for the care of the elderly }\end{array}$ & 2.472 & 0.736 & 3 \\
\hline 3 & $\begin{array}{l}\text { I am keen on knowing the activities and the } \\
\text { programs necessary for the care of the elderly }\end{array}$ & 2.611 & 0.549 & 1 \\
\hline 4 & $\begin{array}{l}\text { I make suggestions that help solve the problems of } \\
\text { the elderly }\end{array}$ & 2.389 & 0.549 & 5 \\
\hline 5 & $\begin{array}{l}\text { I am keen on providing financial resources necessary } \\
\text { for improving the services provided to the elderly. }\end{array}$ & 2.222 & 0.832 & 7 \\
\hline 6 & $\begin{array}{l}\text { I am keen on solving the problems between the } \\
\text { officials and the elderly in a manner that ensures the } \\
\text { quality of service to the elderly }\end{array}$ & 2.389 & 0.599 & 5 \\
\hline 7 & $\begin{array}{l}\text { I am keen on doing the courses related to } \\
\text { developing my experience with dealing with the } \\
\text { elderly }\end{array}$ & 2.556 & 0.607 & 2 \\
\hline \multicolumn{2}{|l|}{2.44} & $\begin{array}{l}\text { High } \\
\text { level }\end{array}$ \\
\hline
\end{tabular}

The previous table shows that:The level of attention of the staff of the elderly care institutions is high with arithmetic average (2.44), first came, I am keen on knowing the activities and the programs necessary for the care of the elderly with arithmetic average (2.611), second came: I am keen on doing the courses related to developing my experience with dealing with the elderly with arithmetic average (2.556), finally, I am keen on providing financial resources necessary for improving the services provided to the elderly with arithmetic average (2.222). 
This may be due to officials seeking the role of the elderly to attract the attention of the elderly and show interest in them, psychological and mental readiness to meet the elderly and goodlooking, attractive smile and effective positive behavior and selfconfidence... Etc. are all considered to be an exciting trigger to awaken the desire of the elderly in order to obtain Service and this is proven by the results of a study (Mahmoud, 2002).

Table (5) shows the participation of the staff of the elderly care institutions $\mathrm{N}=(\mathbf{3 6})$

\begin{tabular}{|l|l|c|c|c|}
\hline No & \multicolumn{1}{|c|}{ Phrase } & A & $\boldsymbol{\sigma}$ & order \\
\hline 1 & $\begin{array}{l}\text { I participate with the teamwork of the institution in } \\
\text { making plans for improving the services provided to } \\
\text { the elderly }\end{array}$ & 2.722 & 0.454 & 1 \\
\hline 2 & $\begin{array}{l}\text { I encourage the family to participate in implementing } \\
\text { the programs of the quality of the services provided } \\
\text { to the elderly }\end{array}$ & 2.306 & 0.668 & 7 \\
\hline 3 & $\begin{array}{l}\text { I am keen on participating in any activity that } \\
\text { benefits the quality of the services provided to the } \\
\text { elderly }\end{array}$ & 2.528 & 0.609 & 4 \\
\hline 4 & $\begin{array}{l}\text { I tell the officials at once when there are problems } \\
\text { facing improvement of services for the elderly, }\end{array}$ & 2.722 & 0.454 & 1 \\
\hline 5 & $\begin{array}{l}\text { I participate in implementing programs that satisfy } \\
\text { the needs of the elderly }\end{array}$ & 2.611 & 0.494 & 3 \\
\hline 6 & $\begin{array}{l}\text { I am keen on participating in the decisions related to } \\
\text { improvement of services for the elderly, }\end{array}$ & 2.472 & 0.506 & 5 \\
\hline 7 & $\begin{array}{l}\text { I participate in the training courses related to } \\
\text { developing the services to the elderly }\end{array}$ & 2.444 & 0.607 & 6 \\
\hline & \multicolumn{2}{|l|}{2.544} & $\begin{array}{l}\text { High } \\
\text { level }\end{array}$ \\
\hline
\end{tabular}

\section{The previous table shows that:}

The level of the participation of the staff of the elderly care institutions is high with arithmetic average (2.544), First came: I participate with the teamwork of the institution in making plans for improving the services provided to the elderly with arithmetic average (2.722), Second came: I tell the officials at once when there are problems facing improvement of services for the elderly with arithmetic average (2.722), Third came: I participate in implementing programs that satisfy the needs of the elderly with arithmetic average (2.611), Finally: I encourage the family to participate in implementing the programs of the quality of the services provided to the elderly with arithmetic average (2.306), This may be due to officials' interest in the elderly participating in the decision-making process related to facing 


\section{Egyptian Journal of Social Work (EJSW) \\ http://ejsw.journals.ekb.eg \\ Print ISSN: 2356-9204 Online ISSN: 2356-9212 \\ Vol 10, Issue 1, June 2020}

their problems and satisfying their needs, and this was confirmed by the results of a study (Kennemer, 2002).

Table (6) shows the level of social responsibility indicators $\mathrm{N}=(36)$

\begin{tabular}{|c|l|c|c|c|c|}
\hline \multirow{2}{*}{ No } & \multirow{2}{*}{ indicators } & \multicolumn{4}{|c|}{ Total indicator average } \\
\cline { 3 - 6 } & & \multicolumn{4}{|c|}{ officials } \\
\cline { 3 - 6 } & & $\mathrm{A}$ & $\sigma$ & level & order \\
\hline 1 & understanding, and perception & 2.583 & 0.347 & high & 1 \\
\hline 2 & Attention & 2,44 & 0.326 & high & 3 \\
\hline 3 & Participation & 2,544 & 0.347 & high & 2 \\
\hline
\end{tabular}

\section{The previous table shows that:}

The level of social responsibility indicators is high, First came: understanding and perception of the staff of the elderly care institutions with arithmetic average (2.583), Second came: the participation of the staff of the elderly care institutions with arithmetic average (2.544), Finally, attention of the staff of the elderly care institutions with arithmetic average (2.44).

Table (7) shows the efficient provision of services to the elderly

\begin{tabular}{|l|l|c|c|c|}
\hline \multirow{2}{*}{ No } & \multicolumn{1}{|c|}{ Phrases } & \multicolumn{1}{|c|}{ The elderly N=(88) } \\
\cline { 4 - 5 } 1 & \multicolumn{1}{|c|}{$\mathbf{A}$} & $\boldsymbol{\sigma}$ & order \\
\hline 2 & $\begin{array}{l}\text { The institution has a specialized staff that help to } \\
\text { satisfy the needs of the elderly }\end{array}$ & 2.114 & 0.734 & 4 \\
\hline & $\begin{array}{l}\text { The social worker diagnoses the needs of the elderly } \\
\text { with the staff of the institution }\end{array}$ & 2.284 & 0.454 & 7 \\
\hline 3 & $\begin{array}{l}\text { The staff of the institution has great experience in } \\
\text { dealing with the problems of the elderly } \\
\text { (psychological- social....etc.) }\end{array}$ & 2.011 & 0.823 & 3 \\
\hline 4 & $\begin{array}{l}\text { The social workers have different skills for } \\
\text { providing services to the elderly }\end{array}$ & 2.341 & 0.477 & 6 \\
\hline 5 & $\begin{array}{l}\text { The institution forms specialized committees to } \\
\text { collect data on the needs of the elderly }\end{array}$ & 1.886 & 0.556 & 5 \\
\hline 6 & $\begin{array}{l}\text { Continuous communication between officials and the } \\
\text { elderly to determine the level of efficiency of the } \\
\text { service provided to them }\end{array}$ & 2.205 & 0.937 & 2 \\
\hline 7 & $\begin{array}{l}\text { The institution organizes training courses for the } \\
\text { staff to achieve the quality of the services provided } \\
\text { to the elderly }\end{array}$ & 1.83 & 0.962 & 1 \\
\hline
\end{tabular}

The previous table shows that: The level of the efficient provision of services to the elderly as determined by the elderly is high with arithmetic average (2.096), First came: The institution organizes training courses for the staff to achieve the quality of the services provided to the elderly with arithmetic average (1.83), 


\begin{tabular}{|c|c|}
\hline Egyptian Journal of Social Work (EJSW) & http://ejsw.journals.ekb.eg \\
\hline Print ISSN: 2356-9204 Online ISSN: $2356-9212$ & Vol 10, Issue 1, June 2020 \\
\hline
\end{tabular}

Second came: Continuous communication between officials and the elderly to determine the level of efficiency of the service provided to them with arithmetic average (2.205), Finally, The social worker diagnoses the needs of the elderly with the staff of the institution with arithmetic average (2.284), This may be due to the Foundation's endeavor to provide an integrated team, to provide resources and capabilities dedicated to improving the quality of service provided to the elderly, and this was demonstrated by the results of a study (Crawley, 2007) (Wotter \& Goakim, 2008).

Table (8) shows easy access to service for the elderly

\begin{tabular}{|l|l|c|c|c|}
\hline \multirow{2}{*}{ No } & \multicolumn{1}{|c|}{ Phrases } & \multicolumn{3}{|c|}{ The elderly N=(88) } \\
\cline { 4 - 5 } 1 & $\begin{array}{l}\text { The institution sets conditions for the elderly to } \\
\text { receive the service }\end{array}$ & 2.557 & 0.544 & 3 \\
\hline 2 & $\begin{array}{l}\text { The institution provides services to the elderly at } \\
\text { appropriate intervals }\end{array}$ & 2.693 & 0.464 & 7 \\
\hline 3 & $\begin{array}{l}\text { There is an understanding between the elderly and the } \\
\text { service providers in the institution }\end{array}$ & 2.568 & 0.498 & 6 \\
\hline 4 & $\begin{array}{l}\text { The social worker overcomes the difficulties the } \\
\text { elderly faces when getting the service }\end{array}$ & 1.398 & 0.578 & 2 \\
\hline 5 & $\begin{array}{l}\text { Clear service delivery procedures for all elderly } \\
\text { people }\end{array}$ & 2.545 & 0.523 & 5 \\
\hline 6 & $\begin{array}{l}\text { The elderly can get the service anytime they need it } \\
\text { The institution responds fast to provide the services } \\
\text { to the elderly }\end{array}$ & 2.318 & 0.891 & 1 \\
\hline 7 & $\begin{array}{l}|c| 284 \\
\text { Total Dimension }\end{array}$ & 2.338 & 4 \\
\hline
\end{tabular}

The previous table shows that: The level of easy access to service for the elderly as determined by the elderly is high with arithmetic average (2.338). First came: The elderly can get the service anytime they with arithmetic average need it (2.318), Second came: The social worker overcomes the difficulties the elderly faces when getting the service with arithmetic average (1.398), Finally, The institution provides services to the elderly at appropriate intervals with arithmetic average (2.693), This may be due to the officials setting easy procedures for the elderly to obtain the service at the time and place he wants, and this is proven by the results of a study (Al-Dmour, 2005). 


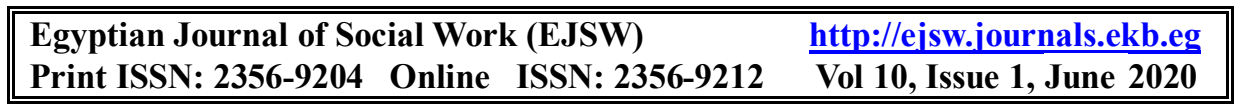

Table (9) shows the continuous improvement of the service provided to the elderly

\begin{tabular}{|l|l|c|c|c|}
\hline \multirow{2}{*}{ No } & \multicolumn{1}{|c|}{ Phrases } & \multicolumn{3}{|c|}{ The elderly N= (88) } \\
\cline { 3 - 5 } 1 & $\begin{array}{l}\text { Accuracy when selecting good manpower } \\
\text { for working for the institution }\end{array}$ & 2.716 & 0.454 & 7 \\
\hline 2 & $\begin{array}{l}\text { The institution constantly organizes } \\
\text { training courses for the staff }\end{array}$ & 1.807 & 0.828 & 4 \\
\hline 3 & $\begin{array}{l}\text { Involving all the staff of the institution in } \\
\text { the process of improving the services }\end{array}$ & 2.011 & 0.809 & 5 \\
\hline 4 & $\begin{array}{l}\text { Interest in involving the elderly in the } \\
\text { process of developing the services } \\
\text { provided to them }\end{array}$ & 1.636 & 0.628 & 6 \\
\hline 5 & $\begin{array}{l}\text { The institution has a clear regulatory policy } \\
\text { to develop services for the elderly }\end{array}$ & 2.273 & 0.906 & 2 \\
\hline 6 & $\begin{array}{l}\text { Holding successive meetings discussing } \\
\text { the constraints of improving services }\end{array}$ & 1.875 & 0.882 & 3 \\
\hline 7 & $\begin{array}{l}\text { Distribution of roles according to the } \\
\text { capabilities and potentials of members in a } \\
\text { manner that ensures improvement of } \\
\text { service }\end{array}$ & 2.17 & 0.925 & 1 \\
\hline \multicolumn{2}{|l|}{ Total Dimension } & High level \\
\hline
\end{tabular}

The previous table shows that: The level of the continuous improvement of the service provided to the elderly as determined by the elderly is high with arithmetic average (2.338), First came: Distribution of roles according to the capabilities and potentials of members in a manner that ensures improvement of service with arithmetic average (2.17), Second came: The institution has a clear regulatory policy to develop services for the elderly with arithmetic average (2.273), Finally, Accuracy when selecting good manpower for working for the institution with arithmetic average (2.716), This may be due to the officials'interest in measuring the services development process and analyzing the strengths and weaknesses in performance in order to continuously improve the services provided to the elderly, and this was proven by the results of a study (Kotler, P. 2010). 


\begin{tabular}{|c|c|}
\hline Egyptian Journal of Social Work (EJSW) & http://ejsw.journals.ekb.eg \\
\hline Print ISSN: $2356-9204$ Online ISSN: $2356-9212$ & $\overrightarrow{\text { Vol 10, Issue 1, June } 2020}$ \\
\hline
\end{tabular}

Table (10) shows the security and safety of the environment in which service is provided to the elderly

\begin{tabular}{|l|l|c|c|c|}
\hline \multirow{2}{*}{ No } & \multicolumn{1}{|c|}{ Phrases } & \multicolumn{3}{|c|}{ The elderly N=(88) } \\
\cline { 4 - 6 } 1 & \multicolumn{1}{|c|}{$\mathbf{A}$} & $\boldsymbol{\sigma}$ & order \\
\hline 2 & $\begin{array}{l}\text { The institution has excellent rooms for the elderly } \\
\text { stay }\end{array}$ & 2.761 & 0.429 & 1 \\
\hline 3 & $\begin{array}{l}\text { The institution has good lighting to suit the elderly } \\
\text { The institution is keen on having regular cleaning } \\
\text { for all its internal departments }\end{array}$ & 2.83 & 0.378 & 4 \\
\hline 4 & $\begin{array}{l}\text { The institution is keen on establishing a suitable } \\
\text { place to receive visitors }\end{array}$ & 2.898 & 0.305 & 6 \\
\hline 5 & $\begin{array}{l}\text { The institution provides an emergency system to } \\
\text { keep the lives of the elderly safe. }\end{array}$ & 2.807 & 0.397 & 3 \\
\hline 6 & $\begin{array}{l}\text { The institution is keen on having specialized } \\
\text { doctors to provide health care for the elderly }\end{array}$ & 2.841 & 0.368 & 5 \\
\hline 7 & $\begin{array}{l}\text { The institution provides the elderly with suitable } \\
\text { healthy food }\end{array}$ & 2.807 & 0.425 & 2 \\
\hline & \multicolumn{2}{|c|}{2.835} & $\begin{array}{c}\text { High } \\
\text { level }\end{array}$ \\
\hline
\end{tabular}

The previous table shows that: The level of the security and safety of the environment in which service is provided to the elderly as determined by the elderly is high with arithmetic average (2.835), First came: The institution has excellent rooms for the elderly stay with arithmetic average (2.761), Second came: The institution provides the elderly with suitable healthy food with arithmetic average (2.807), Finally, The institution is keen on establishing a suitable place to receive visitors with arithmetic average (2.898), This may be due to the officials' endeavors to provide comfortable seats, dining places, capabilities and equipment, staff and activities in a manner that guarantees safety and environmental safety for the elderly, and this is proven by the results of a study (Elley., 2003).

Table (11) shows the level of the indicators of quality of service provided to the elderly:

\begin{tabular}{|l|l|c|c|c|c|}
\hline \multirow{2}{*}{ No } & \multicolumn{2}{|c|}{ Quality of services indicators } & \multicolumn{4}{|c|}{ Total indicator average } \\
\cline { 3 - 6 } & & \multicolumn{4}{|c|}{ The elderly N=(88) } \\
\cline { 3 - 6 } & Efficiency of service delivery & 2.096 & 0.401 & medium & 3 \\
\hline 2 & Easy access to service & 2.338 & 0.265 & medium & 2 \\
\hline 3 & $\begin{array}{l}\text { Continuous improvement of the service } \\
\text { provided to the elderly }\end{array}$ & 2.069 & 0.451 & medium & 4 \\
\hline 4 & $\begin{array}{l}\text { the security and safety of the } \\
\text { environment in which service is } \\
\text { provided to the elderly }\end{array}$ & 2.835 & 0.150 & high & 1 \\
\hline
\end{tabular}


The previous table shows that: The level of the indicators of quality of service provided to the elderly as determined by the elderly is medium, First came: the security and safety of the environment in which service is provided to the elderly with arithmetic average (2.835), Second came: Easy access to service with arithmetic average (2.338), Third came: Efficiency of service delivery with arithmetic average (2.096), Finally, Continuous improvement of the service provided to the elderly with arithmetic average (2.069).

Table (12) shows the main hypothesis test for the study, which is correlation between social responsibility and quality indicators for services for the elderly:

\begin{tabular}{|c|c|c|}
\hline \multirow{2}{*}{$\begin{array}{c}\text { Social Responsibility } \\
\text { Indicators }\end{array}$} & \multicolumn{2}{|c|}{ Quality of services indicators } \\
\cline { 2 - 3 } & Pearson Correlation Coefficient(r) & Indication \\
\cline { 2 - 3 } & 0.510 & significant \\
\hline
\end{tabular}

The previous table shows that: The value of Pearson's correlation coefficient between the independent variable: Indicators of measuring social responsibility (Understanding and perception, attention, participation) and the dependent variable: indicators quality of service (Efficient service delivery, easy access to service, continuous improvement of the service, safety and integrity of the environment in which the service is provided) provided to the elderly is $(0.510)$, which is statistically significant at the (0.05) level, indicating an a moderate direct correlation between the two variables. This makes us accept the main hypothesis of the study "There is a statistically significant direct relationship between the social responsibility of workers in the elderly care institutions and the quality of services provided to them".

Table (13) shows the sub-hypothesis test for the study

\begin{tabular}{|c|c|c|c|c|c|c|c|c|}
\hline \multirow[t]{2}{*}{ Indicators } & \multicolumn{2}{|c|}{$\begin{array}{c}\text { Efficiency of service } \\
\text { delivery }\end{array}$} & \multicolumn{2}{|c|}{ Easy access to service } & \multicolumn{2}{|c|}{$\begin{array}{l}\text { Continuous improvement } \\
\text { of the service provided to } \\
\text { the elderly }\end{array}$} & \multicolumn{2}{|c|}{$\begin{array}{l}\text { the security and safety of } \\
\text { the environment in which } \\
\text { service is provided to the } \\
\text { elderly }\end{array}$} \\
\hline & $\begin{array}{c}\text { Pearson } \\
\text { Correlation }\end{array}$ & $\begin{array}{l}\text { Sig. (2- } \\
\text { tailed) }\end{array}$ & $\begin{array}{c}\text { Pearson } \\
\text { Correlation }\end{array}$ & $\begin{array}{l}\text { Sig. (2- } \\
\text { tailed) }\end{array}$ & $\begin{array}{c}\text { Pearson } \\
\text { Correlation }\end{array}$ & $\begin{array}{l}\text { Sig. (2- } \\
\text { tailed) }\end{array}$ & $\begin{array}{c}\text { Pearson } \\
\text { Correlation }\end{array}$ & $\begin{array}{l}\text { Sig. (2- } \\
\text { tailed) }\end{array}$ \\
\hline $\begin{array}{l}\text { Understanding, } \\
\text { and Perception }\end{array}$ & $\begin{array}{c}-0.203 \\
\text { Not } \\
\text { significant } \\
\end{array}$ & $\begin{array}{c}0.235 \\
\text { Not } \\
\text { significant } \\
\end{array}$ & $\begin{array}{c}0.075 \\
\text { Not } \\
\text { significant } \\
\end{array}$ & $\begin{array}{c}0.664 \\
\text { Not } \\
\text { significant } \\
\end{array}$ & $\begin{array}{c}0.089 \\
\text { Not } \\
\text { significant } \\
\end{array}$ & $\begin{array}{c}0.607 \\
\text { Not } \\
\text { significant } \\
\end{array}$ & $\begin{array}{c}0.094 \\
\text { Not } \\
\text { significant } \\
\end{array}$ & $\begin{array}{c}0.584 \\
\text { Not } \\
\text { significant } \\
\end{array}$ \\
\hline Attention & $\begin{array}{l}0.315 \\
\text { Not } \\
\text { significant }\end{array}$ & $\begin{array}{c}\text { 0.061 } \\
\text { Not } \\
\text { significant }\end{array}$ & $\begin{array}{c}0.339 \\
\text { Not } \\
\text { significant }\end{array}$ & $\begin{array}{l}0.043 \\
\text { significant }\end{array}$ & $\begin{array}{c}0.329 \\
\text { Not } \\
\text { significant }\end{array}$ & $\begin{array}{c}0.050 \\
\text { significant }\end{array}$ & $\begin{array}{c}0.162 \\
\text { Not } \\
\text { significant }\end{array}$ & $\begin{array}{c}0.344 \\
\text { Not } \\
\text { significant }\end{array}$ \\
\hline Participation & $\begin{array}{c}0.598 \\
\text { Not } \\
\text { significant }\end{array}$ & $\begin{array}{c}0.000 \\
\text { significant }\end{array}$ & $\begin{array}{l}0.141 \\
\text { Not } \\
\text { significant }\end{array}$ & $\begin{array}{c}0.413 \\
\text { Not } \\
\text { significant }\end{array}$ & $\begin{array}{c}0.554 \\
\text { Not } \\
\text { significant }\end{array}$ & $\begin{array}{c}0.000 \\
\text { significant }\end{array}$ & $\begin{array}{c}0.601 \\
\text { Not } \\
\text { significant }\end{array}$ & $\begin{array}{c}0.000 \\
\text { significant }\end{array}$ \\
\hline
\end{tabular}


The previous table shows that: There is no relationship between understanding and perception as one of the indicators of social responsibility and indicators of quality of service, which makes us, accept the first sub-hypothesis of the study, which is, "There is no statistically significant correlation between understanding and perception as an indicator of social responsibility and indicators of the quality of services provided to the elderly. While there is a statistically significant positive relationship between interest as one of the indicators of social responsibility and indicators of the quality of services provided for the elderly in the two dimensions (ease of access to service, continuous improvement of service).

And there is also a statistically significant direct relationship between participation as one of the indicators of social responsibility and indicators of the quality of services provided for the elderly in the two dimensions (efficiency of service provision, continuous improvement of the service, safety and integrity of the environment in which the service is provided). This makes us accept the second subhypothesis of the study, which is "There is a statistically significant positive relationship between interest and participation as one of the indicators of social responsibility and indicators of the quality of services provided to the elderly."

\section{- General Discussion of the Research Issues in Light of the Derived Results:}

The study proved the validity of its goals and hypotheses that it seeks to achieve, as it has proven that the level of social responsibility indicators for workers in the elderly care institutions and its relationship to the quality of services provided to them is high, as officials in those institutions work to understand and understand the problems of the elderly and their needs and develop different solutions to confront the problems of the elderly and satisfy their needs, and train them on many different life skills, such as the skill of communication and dialogue with others, so that they can express their problems and needs and understand their social roles to be performed, as officials are interested in attracting the attention of the elderly inside the corporation has to awaken the desire they have to obtain the services they want in a way that enhances the permanent loyalty of the elderly in order to obtain the service and repeat the access to it. In building his society, this is proven by the study of (Wallace, 2007), (Ismail, 2014), (Mahmoud, 2002), (Kennemer, 2002). 
The results of the study also proved that the level of indicators of the quality of services provided to the elderly is average, and that may require the officials of the elderly to make a greater effort to improve the efficiency of providing services provided to the elderly, and to put in place accessible procedures to obtain the service at the time and place that the elderly wants, as well as the continuous improvement of services provided to the elderly during the participation of the elderly in planning services, and the continuous development of these services in a way that guarantees their effectiveness, and also the officials must provide certain characteristics in the environment in which services are provided to the elderly, it must be provided with comfortable seats and places of food, capabilities and preparation, the teamwork and activities that the elderly desire, which reflects on the satisfaction of the elderly with the services provided to them by the elderly homes, and this is proven by the results of a study (Crawley, 2007), (Mohammed, 2009), (Al-Dmour, 2005), (Al-Rashidi, 2008 (Donovan, 2013), (Elley, 2003).

The results of the study were also linked to the quality of service model (Abu Al-Nasr, 2009, p. 295), which clarified several indicators of the quality of service provided to beneficiaries, namely (speed in delivery or efficiency of service provision, providing the service with respect and appreciation to the beneficiaries, setting special and organized regulations for the process of obtaining the service, ease of procedures for obtaining the service, lack of distinction or differentiation between the beneficiaries when providing the service, continuous improvement of the service provided to the beneficiaries through mastering the skills of dealing with the beneficiaries and providing an entrepreneurial spirit to him, taking into account the safety and security of the environment in which the services are provided to the beneficiaries).

\section{Recommendations of the study:}

Studying the efficiency of the indicators of the officials of the elderly care institutions and the return on provision of services to this group, studying the problems that face families of the elderly and how to overcome them, and the problems the social workers face when dealing with the elderly, which hinder the quality of the services provided to the elderly, studying the constraints of the programs' effectiveness of the elderly institutions, studying the needs of the elderly 


\section{References:}

Arabic Language Academy, (2010): The brief dictionary, printed by the Ministry of Education, Book Sector, Cairo.

Abu AlNaser, M, M. (2009): The Art of Social Service Practice, Cairo, AlFajr Publishing and Distribution House.

Abu AlNaser, M, M. (2016): Practice of social service in the field of social responsibility, Alexandria, modern university office.

Al Dhamour, H, H. (2005): Marketing Services, Amman, Wael Publishing House.

Al-Rashidi, Ab- W, M. (2008): The Department of Comprehensive Quality of Social Welfare Institutions for the Elderly in Egypt, research published by the second conference of the Scientific Institute of Social Service in Port Said.

Barton, J., \&Marson, B. (1991): Service Quality: An introduction, Provice of British Columbia Publications.

Carol, A, B., (1999): Corporate Social Responsibility: Evolution of Definitional, University of Georgia, United States, Sage Publication.

Central Agency for Public mobilization and Statistics, (2018): Statistical Yearbook, Cairo.

Crawley, B., (2007): social of elderly African Americans with mental health concerns m USA, Haworth.

Donovan,J. (1013) : Social work In metal Health. Vol H (2) mar.

Eduard, S., (1998): Total Quality Management in Education 'London ، Kogan ،Limited.

Elley, M (2003): falling between two stools how a weak co-operation between the social security and the unemployment. Uk, International Journal, vol. 30.

Eweda, A. (2005): Creative Trends in the Foundation Design of the Elderly Homes, Research Published by the First Regional Conference on the Care of the Elderly, Helwan University.

Fat'halbab, E, A. (2003): The effectiveness of recreational programs in the service of the community in achieving social harmony for the elderly, research published at the 16th Scientific Conference, Faculty of Social Service, Helwan University, Volume 3.

Gerard, T \& Michel, L., (1992): Marketing des services, édition de nord .

Ismail, F, A. (2014): Community Service and The Development of Women's Social Responsibility using Community Dialogue, Research Published in The Journal of Studies in Social Service and Humanities, Faculty of Social Service, Helwan University, Issue 37, Part 6.

Kennemer, K., (2002): Factors predicating social responsibility in college students, Dissertation Abstracts International, Vol. 63, No. 02. 
Korpi, W., \&palme, G., (2008): the paradox of redistribution and strategies of equality welfare state Institution, US, Gournal of American sociology.

Kotler, P. (2010). Marketing Management: Analysis planning: implement and control 'India.

Kyung, H, K.,(2002): The Effect of a reality therapy program on the Responsibility for Elementary school children in Korea, international Journal of Reality Therapy; Fall, Vol. 22, Issue 1 .

Mahmoud, K, K. (2002): Quality management, Amman, Massira Management for Publishing, Distribution and Printing.

Adam, R., \&Saulter, R., (2000): Quality Management Frameworks in the Public Sector Total Quality Management, Vol. 11, No 4.

Michelle, C. (2003): The Role of Parenting Styles in the Development of Social Responsibility, Doctor of Psychology in Clinical Psychology, the Faculty of the Graduate School of Clinical Psychology, George Fox University, Newberg, Oregon.

Mohammad, A, H. (2009): Investment of retired professional leaders in improving the 22nd International Scientific Conference on Social Service, Faculty of Social Service, Helwan University.

Shaiira, H, F. (2013): Evaluation of the Elderly person's sitter project from the perspective of general practice in social work, master's thesis, unpublished, faculty of social work, Helwan University.

Starrett,Rh., (1996): Assessment Of Global Social Responsibility Psychological report, University of Wisconsin Center-Marshfield, Wood County, vol.78.

Suge, J, C., (2005): National Policies on Aging in Korea, center de researches pour la development international, Korea.

Szwarc, P. (2005): Researching Customer Satisfaction and Loyalty 'British library.

United Nations population division department of economic and social affair. (2002), population a binb.

Wallace, L.,(2007) : A Framework for Revitalization or Rural Education and Educational Development, International Institute for Educational Planning 'vol 27.

William, E. \& et.al, (2006): Values and the Perceived Importance of Ethics and Social Responsibility: The U.S. versus China, Journal of International Financial Management, Springer, p270.

World Health Organization, (2018): Fall prevention in older age, summary report.

Ziong, Y., (2008): Policy and Practice of Elderly Cafe in Chummily. 
